\title{
Olmesartan vs ramipril in the treatment of hypertension and associated clinical conditions in the elderly: a reanalysis of two large double-blind, randomized studies at the light of the most recent blood pressure targets recommended by guidelines [Corrigendum]
}

Omboni S, Malacco E, Mallion JM, Volpe M. Clinical

Interventions in Aging. 2015;10:1575-1586.
On page 1584, left column, 4 th row from the bottom, the age indicated should be 65-69 rather than 65-59.
CAS, Scopus and the Elsevier Bibliographic databases. The manuscript management system is completely online and includes a very quick and fair peer-review system, which is all easy to use. Visit http://www.dovepress. com/testimonials.php to read real quotes from published authors. 